\title{
PROSUDBA TRULEŽI STABALA HRASTA KITNJAKA ZVUČNIM TOMOGRAFOM
}

\section{ACOUSTIC TOMOGRAPHY ASSESSMENT OF DECAY IN SESSILE OAK TREES}

\author{
Vinko PAULIĆ ${ }^{1}$, Tomislav ŠKARICA², Damir DRVODELIĆ ${ }^{1}$, Milan ORŠANIĆ ${ }^{1}$
}

\begin{abstract}
SAŽETAK
Urbana stabla i šume doprinose kvaliteti života stanovnika urbanog područja i pružaju brojne koristi. Međutim, stabla u urbanim područjima su izložena različitim abiotskim i biotskim poremećajima koji utječu na njihov razvoj. Gljive truležnice se ističu kao bitan uzročnik pojave loma stabla. Dijagnostički instrumenti koji mjere određena svojstva drva se koriste u arborikulturi kao dopuna vizualnoj prosudbi urbanih stabala. Zvučni tomograf je uređaj koji mjeri brzinu prolaska zvučnih valova kroz drvo u radijalnom i tangentnom smjeru kako bi se prosudile unutarnje greške drva. Cilj istraživanja je bio odrediti veličinu i položaj zdravog i trulog drva te odrediti točnost zvučnog tomografa kod deset stabala hrasta kitnjaka u Parku Maksimir u Zagrebu. Usporedili smo rezultate grafičkih prikaza zvučnog tomografa (tomograme) sa fotografijama presjeka panjeva stabala koja su posječena radi potvrde truleži drva. Trulež drva je bila vidljiva na osam od deset istraživanih stabala koji su imali simptome truleži pri vizualnom pregledu. Trulež drva je potvrđena kod sedam stabala na panjevima nakon sječe. Kod tri stabla zabilježen je početni stadij truleži drva, dok su četiri stabla imala aktivnu trulež drva i pojavu šupljina. Oblik tomograma odgovarao je fotografijama presjeka panjeva kod osam stabala, a pozicija trulog drva je odgovarala fotografijama presjeka panjeva kod devet stabala. Područje trulog drva različitih kategorija je bilo točno prepoznato na tomogramima za šest od deset istraživanih stabala. Zvučni tomograf je podcijenio površinu zdravog drva, precijenio površnu drva u početnim stadijima truleži i točno predstavio područja s aktivnom truleži drva i šupljinama.
\end{abstract}

KLJUČNE RIJEČI: hrast kitnjak, urbana šuma, arborikultura, zvučna tomografija, trulo drvo.

\section{UVOD}

\section{INTRODUCTION}

Stabla i šume važan su dio zelene strukture grada. Oplemenjujući prostor i unaprjeđujući kvalitetu života, stabla imaju važan socijalni, estetski, klimatski, ekološki i gospodarski značaj za urbane prostore (Tyrväinen i dr. 2005, Tikvić i dr. 2017). Šume i stabla u gusto naseljenim područjima zahvaljujući svojoj ekološkoj i estetskoj ulozi utječu na hidrologiju, atmosferu te bioraznolikost u urbanim područjima (Nowak i Dwyer 2007).
Urbana stabla su tijekom svog života u neprekidnom dinamičnom odnosu s okolinom. Izložena su različitim brojnim abiotičkim i biotičkim čimbenicima, od kojih pojedini negativno utječu na njihov razvoj i opstanak. Za razliku od drveća u prirodnim ekosustavima, drveće urbanih sredina u većoj je mjeri izloženo brojnim štetnim utjecajima biotičkog i abiotičkog podrijetla, a spektar biotičkih štetnih čimbenika je drukčiji nego u prirodnom okruženju (Tomiczek i dr. 2008). Jedan od najznačajnijih biotskih štetnih čimbenika koji se javlja na urbanim stablima je trulež drva

\footnotetext{
${ }^{1}$ doc. dr. sc. Vinko Paulić, vpaulic@sumfak.hr, izv. prof. dr. sc. Damir Drvodelić, ddrvodelic@inet.hr, prof. dr. sc. Milan Oršanić, milan.orsanic3@zg.htnet.hr, Sveučilište u Zagrebu, Fakultet šumarstva i drvne tehnologije. Zavod za ekologiju i uzgajanje šuma. Svetošimunska cesta 23, HR-10000 Zagreb

${ }^{2}$ Tomislav Škarica, mag. ing. silv., tskarica1@gmail.com, Serdara Nakića Vojnovića 7, Drniš
} 
koja se prepoznaje po pojavi plodišta gljiva truležnica. Djelovanjem lignikolnih gljiva truležnica zdravo drvo se razara, čime dolazi do pojave trulog drva (Struna Hrvatsko strukovno nazivlje). Pojava truleži kod živih stabala utječe na smanjenje čvrstoće drva, čime se povećava rizik za pojavu loma. To je posebice važno za okoliš urbanih stabala koja se često nalaze u blizini frekventnih lokacija ili objekata urbane infrastrukture, na kojima može nastati velika šteta u slučaju loma stabla.

Radi smanjenja mogućnosti nastanka šteta i ublažavanja rizika od loma stabla, razvijene su brojne metode koje imaju za cilj pravovremeno prepoznati stabla koja prema svojim karakteristikama i položaju predstavljaju povećan rizik od loma (Paulić 2015). Stabla koja imaju najveći stupanj rizika od loma nazivamo opasnim stablima. Ona se ponajprije prepoznaju kroz arborikulturnu prosudbu urbanih stabala pri čemu se, uglavnom vizualnim metodama, prepoznaju stabla s karakteristikama koje mogu dovesti do pojave loma (Paulić i dr. 2015). To su simptomi i greške na stablu koji ukazuju na mjesto mogućeg loma. Greške drva su nepravilnosti ili nedostatci na stablu koje smanjuju volumen zdravoga drva ili umanjuje njegovu trajnost, čvrstoću ili upotrebljivost, dok je simptom pokazatelj neke bolesti ili poremećaja (Struna Hrvatsko strukovno nazivlje). U kontekstu arborikulturne prosudbe opasnih stabala u urbanim sredinama najznačajniji simptomi i greške na stablima su vezane za pojavu plodišta gljiva truležnica i pojavu greške truleži drva. Dok je prilikom vizualne prosudbe stabala simptom plodišta gljiva truležnica relativno jednostavno za prepoznati, vizualnom prosudbom vrlo je teško prosuditi utjecaj truleži drva na smanjenje stabilnosti i čvrstoće kod urbanih stabala. Radi toga se, kao nadopuna vizualnoj prosudbi, koriste razni arborikulturni instrumenti za dijagnostiku opasnih stabala. Oni rade na principu mjerenja određenih svojstva drva koje, ukoliko je zahvaćeno djelovanjem truleži, propada čime dolazi do smanjenja gustoće drva i narušavanja ostalih fizičkih i mehaničkih svojstava (Johnstone i dr. 2010).

Jedan od često korištenih dijagnostičkih instrumenata u arborikulturi je zvučni tomograf. Ovaj instrument mjeri vrijeme prolaska zvučnih valova u radijalnom i tangencijalnom smjeru okomito na žicu drva između većeg broja senzora smještenih oko stabla (Li i dr. 2014). Udarcem čekića po senzorima zvučnog tomografa stvaraju se valovi frekvencije oko $7 \mathrm{kHz}$ čiji signal bilježe ostali senzori koji ga pretvaraju u vrijeme prolaska zvučnih valova (Arciniegas i dr. 2014). Uz poznavanje udaljenosti između senzora može se izračunati brzina prolaska zvučnih valova u više različitih smjerova, čime se dobiva matrica prolaska zvuka kroz unutrašnjost stabla. Korištenjem algoritama za obradu podataka brzine prolaska zvučnih valova kroz drvo, program zvučnog tomografa kreira grafičku interpretaciju mjerenja koja se naziva tomogram (Liang i Fu 2014). Na njemu su brzine prolaska zvuka predstavljene u nekoliko kategorija, koje su simbolizirane s različitim bojama prikaza, a povezane su s promjenama gustoće drva (Allison i dr. 2020). Područja unutrašnjosti stabla u kojima se nalazi degradirano drvo, koje je razoreno djelovanjem gljiva truležnica, prikazano je relativno nižim kategorijama brzine prolaska zvučnih valova.

Zvučna tomografija je nedestruktivna metoda ispitivanja zdravstvenog stanja urbanih stabala koji ima veliku primjernu u arborikulturi, s obzirom da njegovom uporabom ne dolazi do oštećivanja stabala (Bucor 2005), a informacije dobivene mjerenjem omogućuju lociranje grešaka drva i procjenu njihove veličine, oblika i tehničkih svojstava (Nicolotti i dr. 2003). Međutim, na točnost lociranja grešaka drva na tomogramu utječu određeni faktori poput algoritma za obradu brzina zvuka, broja senzora zvučnog tomografa, strukture drva, (Espinosa i dr. 2019), geometrije oblika stabla (Rust 2017), gljiva truležnica i vrste drveća i koja se ispituje (Deflorio i dr. 2018) te pojave pukotina u drvu (Wang i dr. 2007). Stoga je posebno važno prilikom prosudbe opasnih stabla, ukoliko se koristi zvučni tomograf, točno interpretirati izmjerene rezultate i poznavati čimbenike koji utječu na dobivene tomograme.

Cilj istraživanja je bio odrediti veličinu i položaj područja zdravog i trulog drva kod urbanih stabla korištenjem zvučnog tomografa. Točnost prikaza tomograma i njihova usporedba sa stvarnim stanjem bila je određena nakon sječe istraživanih stabala, čime se dobila potvrda izmjerenih rezultata zvučnog tomografa.

\section{MATERIJAL I METODE MATERIAL AND METHODS}

\section{Područje istraživanja - Study area}

Istraživanje je provedeno $\mathrm{u}$ gradu Zagrebu, sjeverni dio Parka Maksimir $\left(45,82^{\circ} \mathrm{N} ; 16,01^{\circ} \mathrm{E}\right)$ u mješovitoj sastojini hrasta kitnjaka i običnog graba (Slika 1). Površina sjevernog dijela parka Maksimir, koji ima obilježja urbane šume je oko 120 ha. Klima na prostoru Maksimira je humidnija u odnosu na središnji dio grada Zagreba, pri čemu srednja godišnja temperatura zraka iznosi $10,6{ }^{\circ} \mathrm{C}$, dok je srednja godišnja količina oborina 853,7 mm (Ugarković i dr. 2021). Park Maksimir je ispresijecan s brojnim pješačkim stazama koje služe za kretanje i boravak posjetitelja. Sigurnost posjetitelja, koji u Park Maksimir uglavnom dolaze radi boravka u prirodi i rekreacije, važna je zadaća prilikom upravljanja ovom urbanom šumom (Vitasović Kosić i Aničić 2005).

\section{Terenska izmjera stabala - Field measurements on trees}

Na stablima koja se nalaze u blizini pješačkih staza u Parku Maksimir obavljen je arborikulturni vizualni pregled VTA 


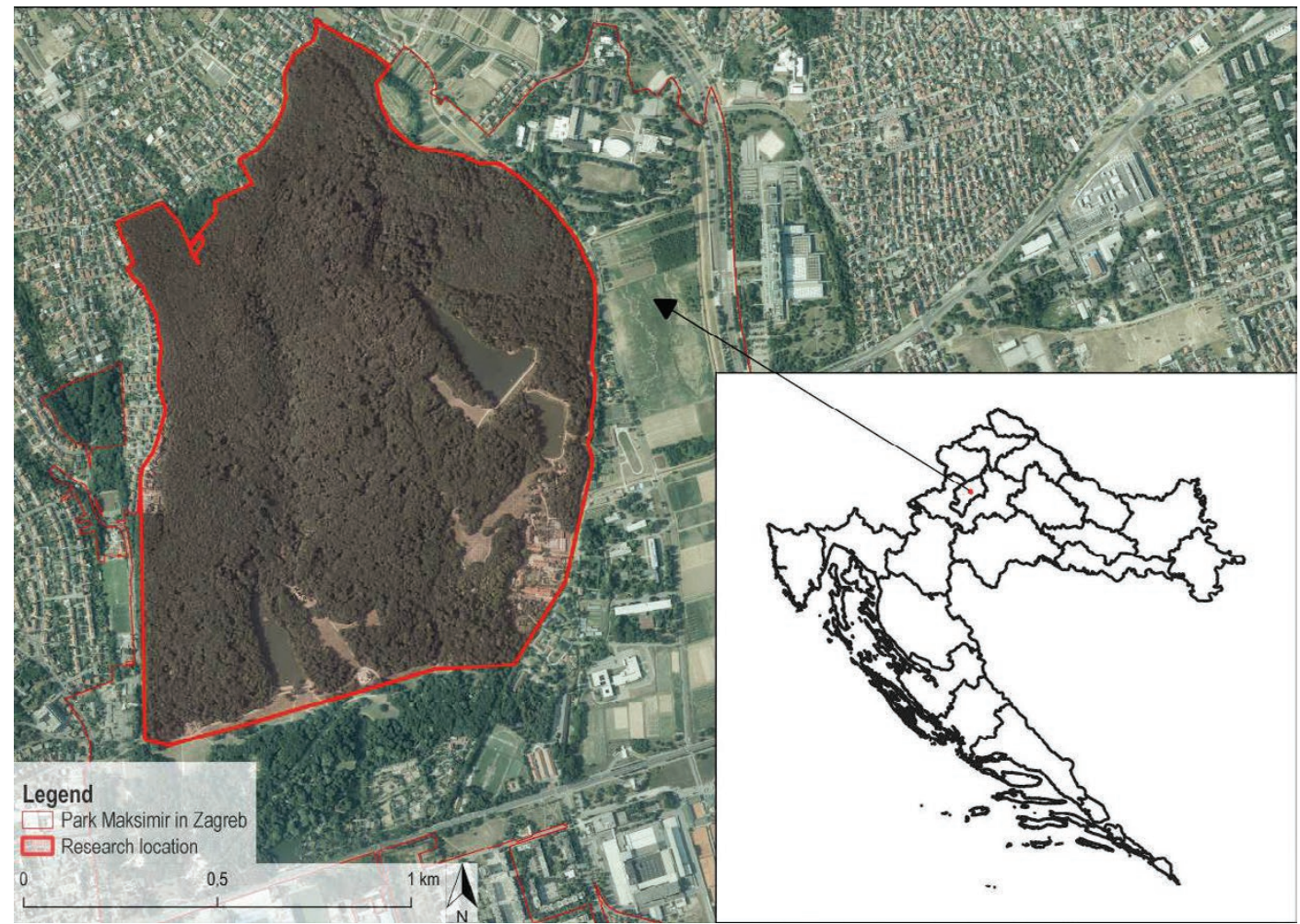

Slika 1. Područje istraživanja

Fig. 1. Study area

metodom (Mattheck i Breloer 1994). Pri tome su evidentirana stabla sa simptomima koji ukazuju na trulež drva poput plodišta gljiva truležnica, ozljede kore, truleži drva na žilištu i ostalih pokazatelja narušavanja optimalnog mehaničkog stanja (Mattheck 2007). Stabla s takvim simptomima su radi svojih karakteristika i položaja uz pješačke staze smatrana kao potencijalno opasna stabla te su dodatno ispitivana korištenjem arborikulturnih dijagnostičkih instrumenata. Za ovo istraživanje je odabrano 10 starih stabala hrasta kitnjaka (Quercus petraea (Matt.) Liebl.), koja su nakon vizualnog pregleda ispitivana zvučnim tomografom. Dodatni kriterij selekcije za ova stabla je bila mogućnost sječe nakon ispitivanja, kako bi se izvršila provjera dobivenih rezultata. Stabla su se nalazila na relativno maloj udaljenosti jedno od drugoga, čime je osiguran homogeni utjecaj stanišnih uvjeta na njihov razvoj. Promjeri panjeva koji

Tablica 1. Deskriptivna statistika za 10 stabala hrasta kitnjaka u Parku Maksimir izmjerenih zvučnim tomografom.

Table 1. Descriptive statistic of 10 sessile oak trees in Park Maksimir measured with acoustic tomograph.

$\begin{array}{lcc}\begin{array}{l}\text { Varijabla } \\ \text { Variable }\end{array} & \begin{array}{c}\text { Aritmetička } \\ \text { sredina } \\ \text { Arithmetic } \\ \text { mean }\end{array} & \begin{array}{c}\text { Min - Max } \\ \text { Min - Max }\end{array} \\ \begin{array}{l}\text { Visina mjerenja }(\mathrm{m}) \\ \text { Height of measurement }(\mathrm{m})\end{array} & 1,0 & 0,2-1,9 \\ \begin{array}{l}\text { Promjer stabla na visini mjerenja }(\mathrm{cm}) \\ \text { Tree diameter at measurement height }(\mathrm{cm})\end{array} & 64 & 44-82\end{array}$

su ostali nakon sječe stabala su bili između 44 i $82 \mathrm{~cm}$, dok su visine na kojima su vršena ispitivanja bile u rasponu od 0,2 do $1,9 \mathrm{~m}$ (Tablica 1 ).

\section{Opis izmjere zvučnim tomografom - Description of acoustic tomography measurement}

Za određivanje udjela zdravog drva kod stabla hrasta kitnjaka korišten je zvučni tomograf $\mathrm{ARBOTOM}^{\odot}$ (Rinntech-Metriwerk GmbH \& Co. KG, Heidelberg, Njemačka). Instrument se sastoji od većeg broja senzora (tipično 2-24) koji se kružno postavljaju oko stabla. Prilikom izmjere, udarcem čekića na senzor, stvara se zvučni val koji putuje kroz drvo do ostalih senzora. Vrijeme koje je potrebno valu za put između pojedinih senzora, bilježi se i preračunava u matricu brzine prolaska zvučnih valova iz koje se kreira tomogram. Brzina zvučnih valova u drvu je utjecajna modulom elastičnosti (MOE) i gustoćom drva koji mogu biti umanjeni djelovanjem gljiva truležnica (Brazee i dr. 2011). Područja na stablu kroz koja zvučni valovi sporije prolaze označena su različitim bojama na tomogramu u odnosu na dijelove na kojima zvučni valovi prolaze brže, za koje se pretpostavlja da ih čini zdravo drvo najveće gustoće (Rinn 2012). Za bilježenje vremena prolaska zvučnih valova između 12 senzora zvučnog tomografa kroz drvo i izradu tomograma korišten je računalni program ARBOTOM $^{\circledast}$ v2.0.4 (RinntechMetriwerk GmbH \& Co. KG, Heidelberg, Njemačka). 


\section{Analiza rezultata izmjere zvučnim tomografom - Description of acoustic tomography measurement}

Računalni program $\mathrm{ARBOTOM}^{\circledR}$ izmjerene brzine prolaska zvučnih valova na tomogramima prikazuje u tipičnom rasponu za ispitivanu vrstu drveća. Pri tome se mogu razlučiti različita područja prolaska zvučnih valova koje su izdvojena u nekoliko kategorija ovisno o izračunatoj brzini širenja zvuka kroz drvo. Na tomogramima ispitivanih stabala mogu se razlučiti četiri kategorije koje predstavljaju opis stanja razgradnje drvnog tkiva djelovanjem lignikolnih gljiva truležnica kod živih stabala (Marra i dr. 2018). Kategorija 1 predstavlja zdravo drvo najveće gu- stoće koje je na tomogramima prikazano zelenom bojom, dok se kategorija 2 odnosi na početak razgradnje drva i predstavljena je na tomogramima žutom bojom. Daljnjom aktivnošću gljiva truležnica dolazi do aktivne razgradnje strukture drva, što je predstavljeno kao kategorija 3, koja je crvene boje na tomogramu. Kategorija 4, koja je na tomogramima predstavljena ljubičastom bojom odnosi se na šupljine koje nastaju konačnom razgradnjom drva (Tablica 2).

Radi određivanja površine određene kategorije drva na tomogramima 10 ispitivanih stabala hrasta kitnjaka korišten je program ImageJ (Schneider i dr. 2012).

Tablica 2. Određivanje različitih kategorija stanja drva s obzirom na boju tomograma i RGB vrijednost nijanse određene na fotografiji presjeka panja. Table 2. Rules for different wood condition category based on tomogram color and RGB Hue value determined on stump cross section photography.

$\begin{array}{lccc}\text { Kategorija stanja drva } & \text { Opis stanja drva } & \text { Boja tomograma } & \text { RGB vrijednost nijanse } \\ \text { Wood condition category } & \text { Wood condition description } & \text { Tomogram color } & \text { RGB Hue value } \\ \text { Kategorija 1 } & \text { Zdravo drvo } & \text { Zelena } \\ \text { Category 1 } & \text { Sound wood } & \text { Green } & 70-110 \\ \text { Kategorija 2 } & \text { Početna trulež drva } & \text { Žuta } & 20-70 \\ \text { Category 2 } & \text { Incipient wood decay } & \text { Yellow } \\ \text { Kategorija 3 } & \text { Aktivna trulež drva } & \text { Crvena } & \\ \text { Category 3 } & \text { Active wood decay } & \text { Red } & 0-20 \\ \text { Kategorija 4 } & \text { Šupljina } & \text { Ljubičasta } & 180-255 \\ \text { Category 4 } & \text { Cavity } & \text { Purple }\end{array}$
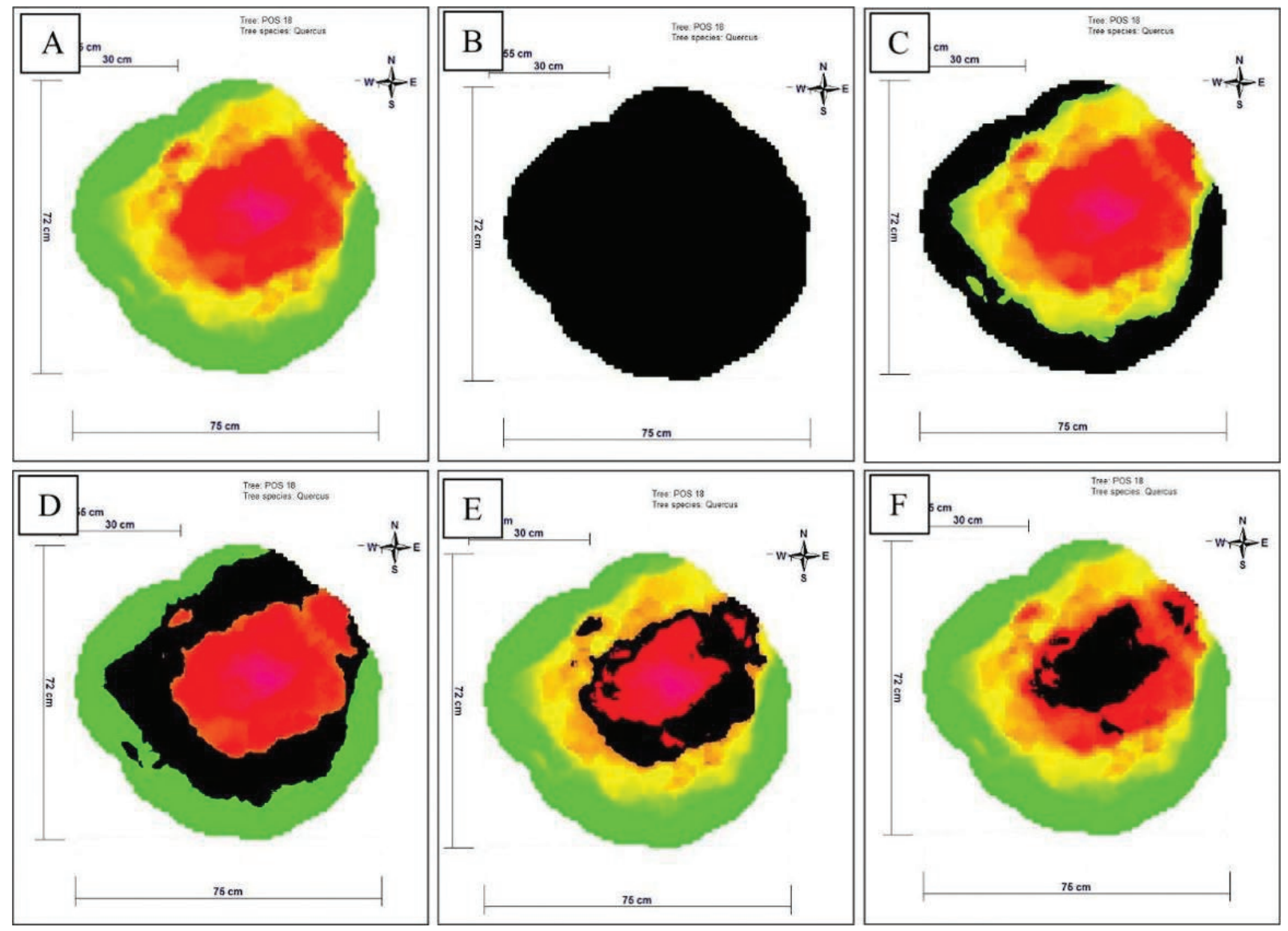

Slika. 2. Izdvajanje i izračun površina različitih kategorija stanja drva na tomogramima pomoću ImageJ programa.

Fig. 2. Differentiation of different wood condition category area and its calculation on tomograms with Image J software. 


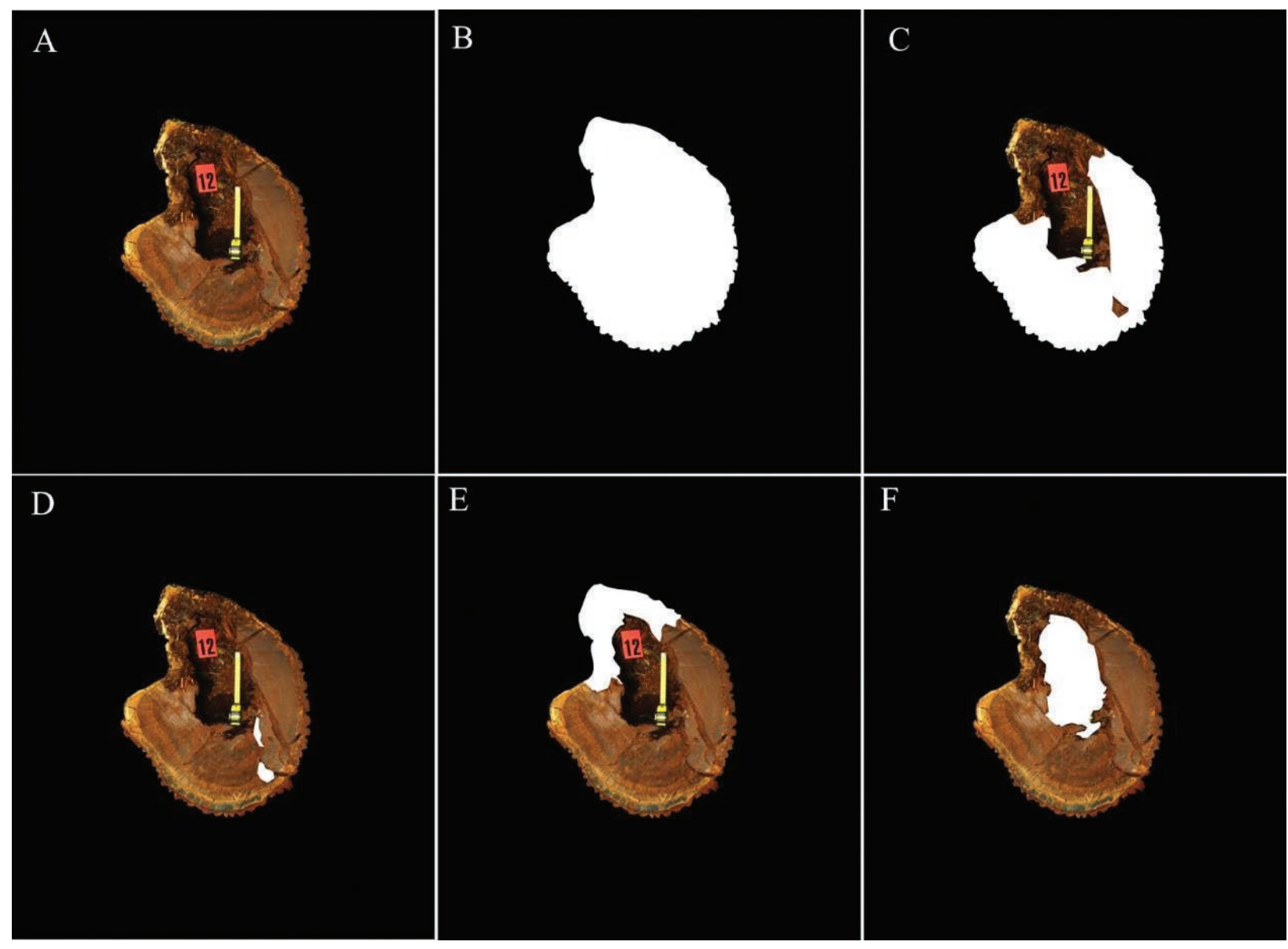

Slika 3. Izdvajanje i izračun površine različitih kategorija stanja drva s fotografija korištenjem ImageJ programa. Bijelom bojom su označene izdvojene površine.

Figure 3. Differentiation of different wood condition category area and its calculation from stump photographs with ImageJ software. Differenced areas were marked with white colour.

Izračun površine različitih kategorija stanja drva na tomogramima se radio prema modificiranoj metodologiji Gilberta i dr. (2016) kod koje se koristi manipulacija nijansi boja prema HSB modelu. HSB model boje analizira prema nijansi (engl. Hue), zasićenju (engl. Saturation) i svjetlini (engl. Brightness).Za analizu površine drva na tomogramima su izdvojene četiri različite kategorije koje smo svrstali u određene HSB parametre nijanse, zasićenja i svjetline boje. Za sve kategorije drva na tomogramima skala zasićenja je bila u rasponu od 140 do 255 , a skala svjetline od 170 do 255. Raspon na skali nijanse boje se razlikovao po kategorijama pretpostavljenog stanja drva na tomogramima. Za prvu kategoriju (zdravo drvo) koristio se raspon od 70 do 110, drugu kategoriju od 20 do 70, treću od 0 do 20, dok je četvrta kategorija (šupljine) bila u rasponu od 180 do 255 (Škarica 2019) (Tablica 2).

Tomogrami su postavljeni u mjerilo kako bi dobili broj točaka (piksela) koji odgovara dužini od $1 \mathrm{~cm}$ (Slika 2a). Zatim je određena ukupna površina tomograma (Slika $2 b$ ) te površine četiri različite kategorija opisa stanja drva (slika 2c- 2f).
Opis izračuna površine trulog drva na fotografijama - Description of decayed wood area measurements on photographs

Nakon izmjere zvučnim tomografom, deset stabala hrasta kitnjaka je posječeno na visini gdje je napravljena izmjera. Panjevi koji su ostali nakon sječe su fotografirani digitalnim fotoaparatom Olympus OM-D E-M1. Prije fotografiranja, označene su pozicije senzora i postavljen je metar kao mjerilo radi kalibracije udaljenosti na panju i izgleda unutrašnjeg presjeka drva (Slika 3). Stanje i površina pojedinih kategorija razgradnje drva na presjeku ispitivanih stabala je određeno prema vizualnoj prosudbi stupnja biološke degradacije drva uz povremenu dodatnu potvrdu Knife probing test metodom (Larjavaara i Muller-Landau 2010). Kao i kod analize tomograma, na taj način su izdvojene četiri različite kategorije opisa stanja drva na presjeku posječenih panjeva (Tablica 2).

Za izmjeru površine razgrađenog drva na fotografijama panjeva posječenih stabala također je korištena analiza fotografija kroz program ImageJ (Abramoff i dr. 2004). Dimenzije točki (piksela) dobivene su korištenjem kalibracije 
fotografije s mjerne vrpce koju smo postavili na panj (Slika 3a). Zatim smo odredili ukupnu površinu presjeka panja (Slika 3b), kao i površine poligona pojedinih kategorija drva (Slika 3c-f). Njihovim zbrajanjem dobili smo površinu ci- jele kategorije. Usporedbom površina pojedinih kategorija s ukupnom površinom određeno je postotno učešće pojedine kategorije stanja drva na fotografijama panjeva posječenih stabala.

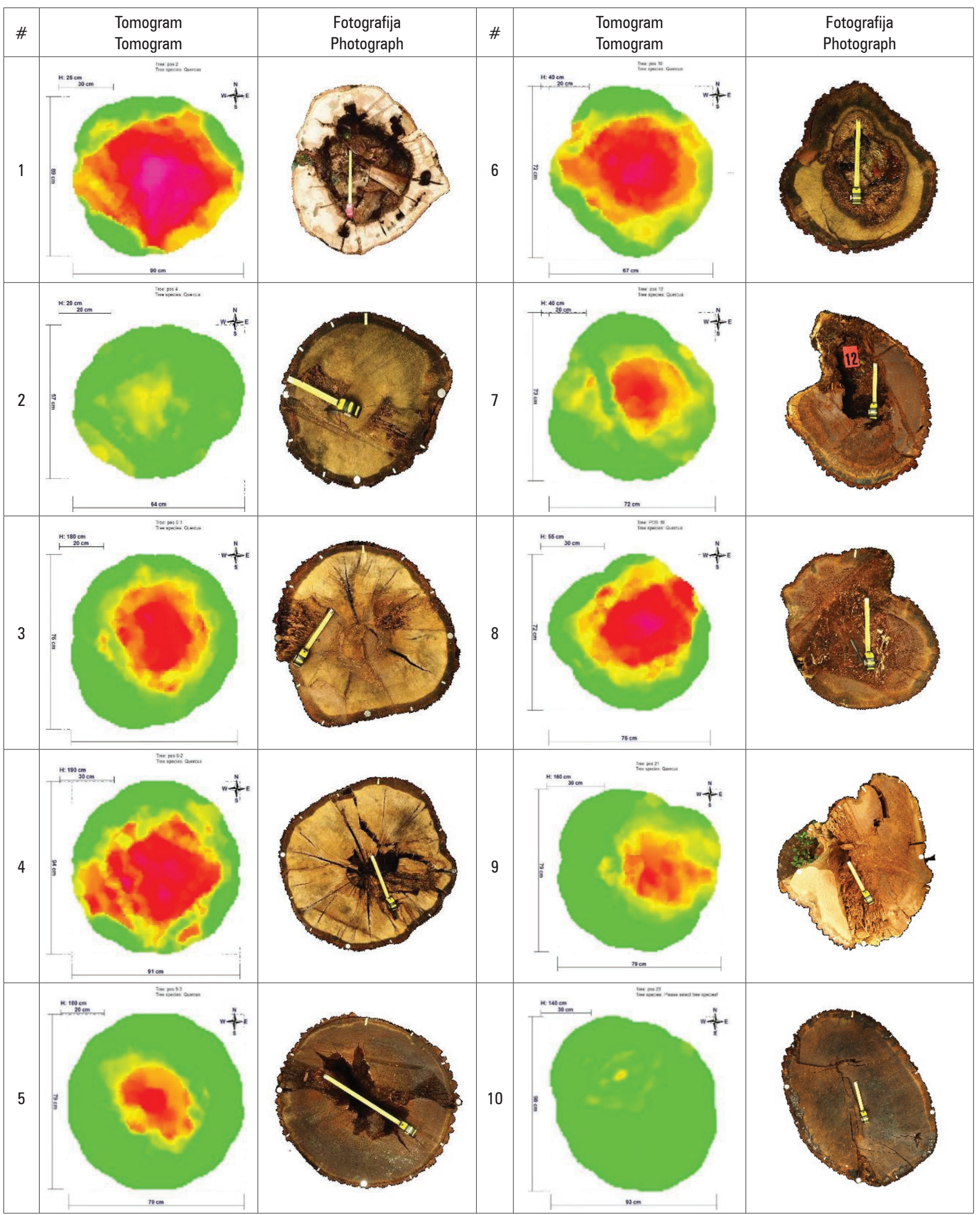

Slika 4. Usporedba tomograma i fotografija panjeva kod 10 stabala hrasta kitnjaka.

Fig. 4. Comparison of tomograms and stumps photographs on 10 sessile oak trees. 


\section{Statistička analiza podataka - Statistical data analysis}

Za usporedbu površine izdvojenih kategorija opisa stanja drva između tomograma i fotografija panjeva posječenih stabala korišten je neparametrijski Wilcoxonov test na osnovi ekvivalentnih parova (engl. Wilcoxon Matched-pairs signed Rank Test), s obzirom da podaci nisu imali normalnu distribuciju. Statistička analiza podataka provedena je u programu Statistica 13 (TIBCO Software Inc. 2018).

\section{REZULTATI \\ RESULTS}

\section{Usporedba tomograma i fotografija panjeva hrasta kitnjaka - Comparison of tomograms and photographs of sessile oak stumps}

Nakon sječe istraživanih stabala, obavljena je kvalititativna usporedba tomograma i fotografija panjeva hrasta kitnjaka (Slika 4). Stabla na kojima su obavljena mjerenja zvučnim tomografom imala su simptome koji ukazuju na prisutnost truleži, međutim ona je bila vidljiva na osam od deset tomograma, dok za dva stabla nije potvrđena prisutnost trulog drva nakon mjerenja zvučnim tomografom. Pregledom panjeva posječenih stabala utvrđeno je prisutnost trulog drva kod sedam stabala, dok je unutrašnje stanje tri stabala bilo zdravo. Od sedam stabala na kojima je potvrđena prisutnost trulog drva, kod tri stabla su procesi razgradnje drva bili uglavnom u početnom stadiju, dok su četiri stabla većinom bila zahvaćena procesima jače razgradnje i razvojem šupljina.

Usporedbom tomograma i fotografija vidljivo je da kod 8 od 10 stabala oblik tomograma prati oblik panja s fotografije. Zvučni tomograf je uspješno prikazao položaj razgrađenog dijela drva kod devet od deset istraživanih stabala hrasta kitnjaka.

Usporedba stanja razgradnje drva na tomogramima i fotografijama - Comparison of wood decay condition on tomograms and photographs

Usporedbom stanja razgradnje drva na tomogramima i fotografijama određeni su različiti površinski udjeli za četiri kategorije (Slika 5). Kategorija 1, koja predstavlja zdravo

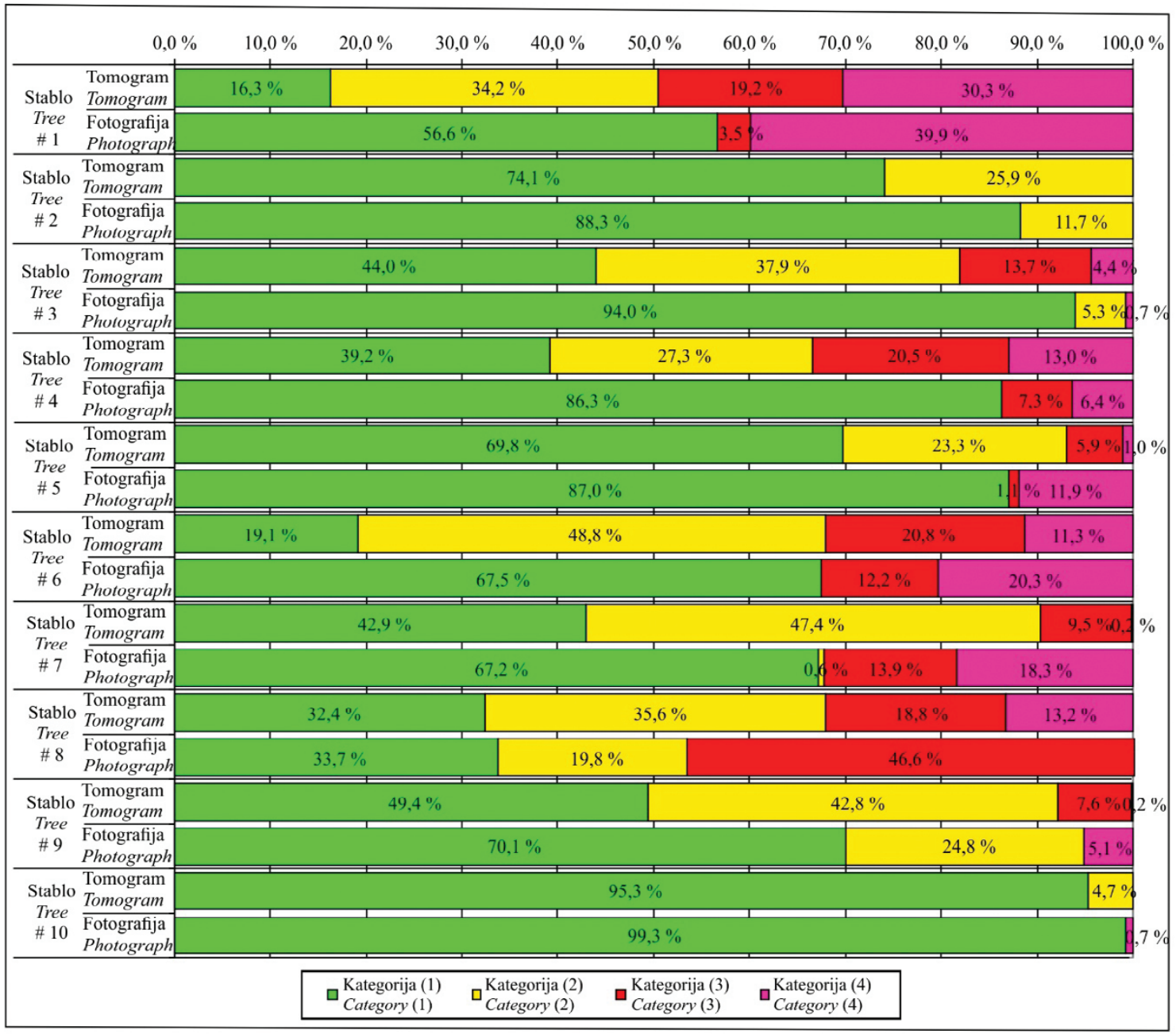

Slika 5. Usporedba stanja razgradnje drva na tomogramima i fotografijama kod 10 stabala hrasta kitnjaka.

Fig. 5. Comparison of wood decay condition on tomograms and photographs on 10 sessile oak trees. 
drvo, bila je prisutna kod svih stabala na tomogramima i fotografijama. Kategorija 2, početna razgradnja drva, određena na deset tomograma, međutim na fotografijama panjeva bila je vidljiva samo kod pet posječenih stabala. Veće razlike između tomograma i fotografija bile su kod znatnije natrulog drva unutar kategorija 3 (aktivna trulež drva) i 4 (šupljine). Na tomogramima kod osam stabala bila je prisutna kategorija 3 i 4 stanja drva, dok je na fotografijama presjeka panjeva kategorija 3 bila prisutna na šest, a kategorija 4 kod osam stabala.

Udio površine kategorija stanja drva prikazanih na tomogramima uspoređeni su s istim kategorijama na fotografijama kod istraživanih stabala. Najveća razlika u udjelu kategorije stanja drva dobivena je kod zdravog drva (kategorija 1). Na svim fotografijama stvarnog stanja udio zdravog drva bio je veći nego što je to određeno na tomogramima. Prosječno učešće kategorije 1 (zdravo drvo) na tomogramima bilo je za 26,8 \% manje od stvarnog stanja na fotografijama panjeva stabala hrasta kitnjaka. Kod kategorije 2 (početna trulež drva) utvrđena je obrnuta situacija, tako da je kod svih stabala udio površine početne razgradnje drva bio veći na tomogramima nego na fotografijama stvarnog stanja. Prosječno gledano, kategorija 2 stanja drva bila je za $26,6 \%$ više zastupljena na tomogramima u odnosu na fotografije presjeka panjeva. $\mathrm{Za}$ kategorije 3 i 4 ustanovljena su u prosjeku manja odstupanja između tomograma i fotografija, u iznosu do $3,2 \%$ površine drva. Usporedbom razlika udjela površine trulog drva kod tomograma i fotografija stvarnog stanja ističu se veće razlike kod četiri od deset istraživanih stabala. Udio jače razgrađenog trulog drva (kategorija 3 aktivna trulež drva i kategorija 4 šupljine) na tomogramima kod dva stabla bio je precijenjen (za 17,4 \% i 19,8 \%) zbog sraslih pukotina unutar debla. Kod dva stabla udio jače razgrađenog trulog drva bio je potcijenjen na tomogramima (za 14,6 \% i 22,5 \%) zbog nepravilno reproduciranog oblika stabla (žilišta) i asimetrično smještene truleži.
Wilcoxonovim testom na osnovi ekvivalentnih parova (engl. Wilcoxon Matched-pairs signed Rank Test) uspoređena je površina različitih kategorija drva između tomograma i fotografija presjeka panjeva (Tablica 3). Kod zdravog drva (kategorija 1) i početne razgradnje (kategorija 2) utvrđena je statistički značajna razlika $(\mathrm{p} \leq 0,05)$ između učešća površine drva na tomogramima i fotografijama, dok kod kategorija 3 i 4 nije bilo značajnih razlika u udjelu površina trulog drva (aktivna trulež i šupljine).

Rezultati razlika udjela površina različitih kategorija stanja drva na tomogramima i fotografijama stvarnog stanja ukazuju da je kod fotografija stabla na terenu (panj) teže razlučivanje površina između kategorija 1 (zdravo drvo) i 2 (početne faze razgradnje drva), u odnosu na drvo kategorija 3 (aktivna trulež) i 4 (šupljine) gdje nije bilo značajnih razlika u površinama.

\section{RASPRAVA DISCUSSION}

Rezultati ovog istraživanja pokazuju da je korištenjem zvučnog tomografa $\mathrm{ARBOTOM}{ }^{\oplus}$ kod osam od deset stabala utvrđena prisutnost trulog drva na tomogramima, dok je vizualnom potvrdom rezultata određena trulež drva kod 7 stabala. Uporaba arborikulturnih dijagnostičkih instrumenta se preporuča kao nadopuna vizualnoj prosudbi stabala, s ciljem određivanja veličine i položaja trulog drva u unutrašnjosti stabla s obzirom da aktivnost gljiva truležnica dovodi do narušavanja strukturne stabilnosti stabla (Leong i dr. 2012). Odabir stabala za istraživanje se temeljio na zapažanjima iz vizualne prosudbe, pri kojoj su na stablima prepoznati simptomi i greške drva koje upućuju na razgradnju drva. Kako kod dva stabla, unatoč simptomima koji su na to ukazivali, nije određena trulež drva na tomogramima, pretpostavljamo da se radi od početnim stadijima zaraze gljiva truležnica. Kod vrsta drveća, koje imaju veću gustoću i trajnije drvo, poput hrasta

Tablica 3. Usporedba učešća površine različitih kategorija stanja drva između tomograma i fotografija presjeka panjeva Wilcoxonovim testom na osnovi ekvivalentnih parova.

Table 3. Comparison of different wood condition area category between tomograms and photographs of stumps cross section using Wilcoxon Matchedpairs signed Rank Test.

\begin{tabular}{|c|c|c|c|c|}
\hline $\begin{array}{l}\text { Parovi varijabli } \\
\text { Pair of Variables }\end{array}$ & $\mathrm{N}$ & $\mathrm{T}$ & Z & $\mathrm{p}$ \\
\hline $\begin{array}{l}\text { Tomogram kategorija } 1 \& \text { Fotografija kategorija } 1 \\
\text { Tomograph category } 1 \& \text { Photography category } 1\end{array}$ & 10 & 0,00 & 2,803060 & 0,005062 \\
\hline $\begin{array}{l}\text { Tomogram kategorija } 2 \& \text { Fotografija kategorija } 2 \\
\text { Tomograph category } 2 \& \text { Photography category } 2\end{array}$ & 10 & 0,00 & 2,803060 & 0,005062 \\
\hline $\begin{array}{l}\text { Tomogram kategorija } 3 \& \text { Fotografija kategorija } 3 \\
\text { Tomograph category } 3 \& \text { Photography category } 3\end{array}$ & 8 & 9,00 & 1,260252 & 0,207579 \\
\hline $\begin{array}{l}\text { Tomogram kategorija } 4 \& \text { Fotografija kategorija } 4 \\
\text { Tomograph category } 4 \& \text { Photography category } 4\end{array}$ & 9 & 14,00 & 1,006993 & 0,313939 \\
\hline
\end{tabular}

* Označene vrijednosti su značajne na razini $\mathrm{p}<0,05$

${ }^{\star}$ Marked values are significant at $p<0,05$ 
kitnjaka, razgradnje drva djelovanjem gljiva truležnica se događa sporije (Sabadi 1996).

Zvučni tomograf uspješno je prikazao oblik tomograma koji prati oblik presjeka stabla s fotografije stvarnog stanja s terena u osam od deset slučajeva. Oblik presjeka je osim načinom postavljanja i nepravilnošću oblika uvjetovan is brojem senzora koji se koriste za izmjeru. Korištenjem većeg broja senzora moguće je dobiti veću rezoluciju, čime se povećava preciznost mjerenja. U istraživanju Tarasiuk i dr. (2007) provedenom na običnom boru u Poljskoj korišteno je šest senzora za mjerenje $\mathrm{ARBOTOM}^{\bullet}$ tomografom. Oni zaključuju da tomogrami sliče, ali ne daju istovjetan oblik stvarnom stanju na terenu zbog malog broja senzora, te preporučuju povećanje broja senzora za bolje rezultate. Kod nas je u istraživanju korišten komplet

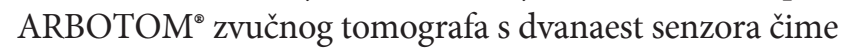
se dobije veća gustoća pravaca prolaska zvuka, a time i kvalitetnija rezolucija na tomogramima. Preporuke za povećanje broja senzora zvučnog tomografa iznose Liang $i$ Fu (2014). Problem prikaza stvarnog stanja unutrašnjeg stabla na tomogramima ovisi o geometriji oblika stabla koji se ispituje. Kod kružnog presjeka, s malim odstupanjem može se očekivati uspješnija reprodukcija unutrašnjeg stanja stabla. Kod modela zvučnog tomografa ARBOTOM ${ }^{\odot}$ postavljanje geometrijskog oblika događa se na način da se umanjuje ili povećava odstupanje od kružnog oblika, čime se uspješnije reproducira oblik stabla na mjestu mjerenja (Rinn 2012). Međutim, kod mjerenja kompleksnih oblika stabla, poput žilišta, vrlo je bitno točno izmjeriti pozicije senzora, jer se njima utječe na izmjerenu brzinu prolaska zvučnih valova, oblik tomograma i veličinu natrulog dijela drva (Rust 2017). Prema Gilbertu i dr. (2016) pravilno postavljanje senzora na stabla koja nemaju pravilan kružni oblik debla bitno je za dobivanje kvalitetnijih rezultata mjerenja zvučnim tomografom i smanjenja grešaka mjerenja koje dovode do razlika u površini zdravog i trulog drva. Brzina prolaska zvučnih valova je ovisna o putu koji zvučni val prijeđe u jedinici vremena, te stoga svaka greška u izmjeri udaljenosti između senzora dovodi do pogrešnog prikaza na tomogramu. U našem istraživanju kod dva stabla, na kojima nije uspješno prikazan oblik presjeka panja s fotografije, na tomogramu je utvrđeno podcjenjivanje udjela znatnije trulog drva unutar kategorija 3 (aktivna) i 4 (šupljine) za 14,6 \% i 22,5 \% u odnosu na stvarno stanje.

Osim uspješne reprodukcije oblika stabla, koji je bitan preduvjet za određivanje preciznosti instrumenta, važno je poznavanje preciznosti izmjere samog instrumenta koje se očituje u uspješnom prikazu unutrašnjeg stanja drva kod živih stabala. Često se odluke o uklanjanju ili zadržavanju vrijednih i povijesno važnih stabala donose na temelju pregleda stabla arborikulturnim dijagnostičkim instrumentima poput zvučnog tomografa (van Wassenaer i Richardson 2009). Cristini i dr. (2021) su utvrdili da postoje značajne razlike izmjerenim brzinama zvuka kod različitih modela zvučnog tomografa, međutim razlike u načinu prikaza unutrašnjeg stanja stabla na tomogramima bile su manje izražene. Pri tome je zvučni tomograf ARBOTOM ${ }^{\bullet}$ uspješno prikazao trulo drvo na izmjerenom presjeku, ali ne i šupljinu manjih dimenzija. Sposobnost zvučnog tomografa za određivanje površine trulog drva kod živih stabala ispitivali su Gsell i dr. (2009) te su utvrdili da zvučni tomograf može prepoznati šupljine koje su veće od $5 \%$ površine poprečnog presjeka stabla. Podaci drugih autora pokazuju da, generalno gledano, zvučni tomograf u svojim prikazima na tomogramima podcjenjuje površinu razgrađenog drva. Međutim, istraživanja se razlikuju u postotnom udjelu tih razlika. One su bile u rasponu od manje od $1 \%$ (Ostrovsky i dr. 2017) do 14 \% (Wang i dr. 2009) površine razgrađenog drva. Potrebno je uzeti u obzir da su u tim istraživanjima ispitivane različite vrste drveća s različitim instrumentima, što može objasniti varijabilnost u rezultatima što su pokazali Cristini i dr. (2021). U istraživanju Gilbert i Smiley (2004) uspoređivane su fotografije stvarnog stanja stabla i tomogrami, te se zaključuje da je zvučni tomograf (Picus Sonic Tomograf) uspješan kod uzoraka sa zdravim drvom, dok kod stabala s degradacijom drva zbog truleži daje tomograme koje prikazuju manju površinu truleži od one koje je potvrđena vizualnom usporedbom. Ta razlika bila je u prosjeku do $5 \%$ površine presjeka, a najviša izmjerena razlika bila je $20 \%$. U našem istraživanju utvrđene su značajne razlike u udjelu površine kod kategorija 1 i 2 opisa stanja drva, dok kod kategorija 3 i 4 nije bilo značajnih razlika u udjelu ovih površina kod tomograma i fotografija presjeka panjeva. Razlozi značajnih razlika kod kategorija 1 i 2 mogu se objasniti karakteristikama ovih kategorija i njihovim izdvajanjem na panjevima posječenih stabala. Dok kategorija 1 predstavlja zdravo drvo, kategorija 2 odnosi se na drvo u početnim stadijima razgradnje, koje može biti uvjetovano promjenama vlažnosti i početnom diskoloracijom radi enzimskog djelovanja gljiva truležnica na stanice drva. Poznato je da vlaga drva smanjuje brzinu zvuka (Gurda 1999), dok Brucham i dr. (2019) navode da podcjenjivanje površine oštećenog drva na tomogramima može biti uvjetovano manjom osjetljivosti instrumenta da razluči početne stadije truleži drva. Ovisno o upotrijebljenoj skali boja koje reprezentiraju brzine zvuka može doći do razlike u procijenjenim površinama zdravog ili oštećenog drva. Kod našeg istraživanja zdravo drvo bilo je određeno sa zelenom bojom tomograma, pri čemu je kod svih stabala utvrđen manji iznos zdravog drva na tomogramima nego na fotografijama presjeka panjeva. Međutim, ukoliko se za drvo koje je na tomogramu označeno žutom bojom brzine prolaska zvuka (za koju smo pretpostavili opis stanja početna trulež drva) svrsta u kategoriju zdravog drva i pribroji kategoriji 1, dolazimo do prosječno razlike manje od $1 \% \mathrm{u}$ procjeni površina zdravog drva. Taj rezultat odnosi se na 6 
stabala kojima je uspješno reproduciran oblik na tomogramu i nisu imala pukotinu u unutrašnjosti stabla. $U$ istraživanju Rusta (2017) također je vizualno uspoređivan prikaz tomograma sa stvarnim stanjem drva, međutim tamo je za natrulo drvo korištena druga kategorizacija boja, odnosno raspon brzine prolaska zvučnih valova kroz drvo. U tom istraživanju sve površine gdje je na tomogramu utvrđena ružičasta, crvena i tamno narančasta boja, klasificirane su kao trulo drvo, međutim žuta boja je klasificirana pod zdravo drvo. Osjetljivost tomograma na udio različitih boja pokazali su Burcham i dr. (2019) primjenom zvučnog tomografa $\mathrm{PiCUS}^{\circledR} 3$ kod kojeg su primjenom tri boje iz skale tomograma dobili razliku površinom oštećenog dijela i tomograma od $2 \%$, dok su kod dvije boje iz tomograma dobili razliku od prosječno $14 \%$.

Yue i dr. (2019) su uspoređujući tomograf koji mjeri električni otpor sa zvučnim tomografom zaključili da je zvučni tomograf uspješniji kod uznapredovale razgradnje drva kada su prisutne šupljine i veći udio razgrađenog drva, dok se početni stadiji truleži uspješnije prepoznaju na tomogramu koji mjeri električni otpor drva. To je u skladu s našim rezultatima, gdje je potvrđeno da nema statistički značajnih razlika između tomograma i fotografija kod stabla koja su imala drvo koje je jače razgrađeno aktivnom truleži (kategorija 3) i šupljine (kategorija 4). Iako je za monitoring urbanih stabala poželjno poznavanje pojave truleži koje je karakterizirano s početnim stadijima kolonizacije gljiva truležnica pri čemu dolazi do promjene vlažnosti drva, što se uspješno prepoznaje s tomografom koji mjeri električni otpor (Luo idr. 2019), za arborikulturnu dijagnostiku urbanih stabala od loma stabla važnije je uspješnije poznavanje površina drva koje su značajnije razgrađene djelovanjem gljiva truležnica. Trulež drva dovodi do gubitka čvrstoće drva, čime se povećava rizik od loma stabla. Položaj trulog dijela drva prikazanog na tomogramima hrasta kitnjaka nije odgovarao položaju trulog drva na presjecima panjeva kod jednog od deset primjera. Također, na jednom tomogramu trulo drvo je asimetrično prikazano, za razliku od ostalih 9 tomograma na kojima je trulo drvo prikazano centralno. O položaju trulog drva u deblu stabla uvelike ovisi čvrstoća dijela stabla na savijanje i lom. Čvrstoća debla je najveća ako se truli dio nalazi u centru, dok se opterećenja uzrokovana djelovanjem vanjskih sila najprije prenose na periferne dijelove, a zatim u unutrašnjost stabla. Deflorio i dr. (2008) u istraživanju na gorskom javoru navode kako se trulež drva na perifernim dijelovima debla teže prepoznaje pomoću zvučnog tomograma. Zvučni valovi se većinom susreću u centru debla, te je zbog slabije rezolucije prikaz perifernog dijela tomograma manje precizan od centralnog dijela. $\mathrm{Za}$ uspješnije određivanje čvrstoće debla na savijanje i lom potrebno je precizno odrediti položaj natrulog ili šupljeg dijela stabla, jer on ima značajni utjecaj na izračun momenta otpora presjeka debla (engl. cross section sectional modulus) što su u svom istraživanju pokazali Koizumi i Hirai (2006) na primjerima stabala topole sa značajnim nepravilnostima oblika i različito smještenim šupljinama.

Unatoč tome što nisu utvrđene značajne razlike u udjelu degradiranog drva (kod tomograma i fotografija, kod dva istraživana stabla zvučni tomograf je precijenio udio trulog drva unutar kategorija 3 i 4 (aktivna trulež i šupljine). Razlog ovim razlikama smo utvrdili nakon sječe istraživanih stabala, gdje je bilo vidljivo da su ona u unutrašnjosti centralno imala zvjezdaste srasle pukotine koje nisu bile vidljive vizualnim pregledom stabala VTA metodom prije mjerenja zvučnim tomografom. Wang i dr. (2007) na primjeru crvenog hrasta ukazuju na to da prisutnost pukotina u unutrašnjosti debla negativno utječe na interpretaciju tomograma. Posebno naglašavaju „zvjezdaste“ $i$,zmijolike“ pukotine koje dodatno uvećavaju prikaz degradacije i oštećenja. To se događa zbog nemogućnosti prolaska zvučnih valova kroz pukotine, već oni moraju „kružiti“ oko pukotine te tako povećavaju svoj put, a posljedično i vrijeme potrebno da stignu do drugih senzora. Time se smanjuje njihova brzina, te zbog toga na tomogramu vidimo degradirani dio većim nego na fotografiji stvarnoga stanja. Wang i Allison (2008) savjetuju povećanje broja senzora i smanjenje razmaka među njima kako bi se umanjila pogreška mjerenja, kao i korištenje tehnike mjerenja mehaničkog otpora drva bušenju (tvz. rezistografija) da bi se locirale pukotine u unutrašnjosti stabla.

Buduća istraživanja točnosti prikaza stanja mogu se dopuniti, ispitivanjem mehaničkih svojstava drva, mjerenjem gustoće drva na uzorcima drva kao i ispitivanjem učinka različitih vrsta truleži, čime bi se dobila kvalitetnija interpretacija faktora koji utječu na prikaz unutrašnjeg stanja drva na tomogramima u odnosu na vizualnu kontrolu na stablima.

\section{ZAKLJUČAK CONCLUSION}

Rezultati ovog istraživanja pokazali su da se korištenjem arborikulturnog dijagnostičkog instrumenta zvučnog tomografa mogu uspješno odrediti područja zdravog drva i trulog drva kod urbanih stabala hrasta kitnjaka. Iako su za istraživanje odabrana stara stabla sa simptomima truleži, ona je na tomogramima bila prikazana kod osam od deset istraživanih stabala. Sječom stabala nakon izmjere zvučnim tomografom, trulež drva je utvrđena na presjecima panjeva sedam stabala, od kojih su kod tri stabla procesi razgradnje drva bili uglavnom u početnom stadiju, dok su četiri stabla većinom bila zahvaćena procesima jače razgradnje i razvojem šupljina. Oblik stabla uspješno je prikazan na tomogramima kod osam od deset stabala, dok je položaj trulog drva uspješno prikazan kod devet od deset istraživanih stabala hrasta kitnjaka. 
Kod šest od deset istraživanih stabala udio površina drva različitih kategorija stanja na tomogramima potvrđen je usporedbom sa stvarnim stanjem. U ovom istraživanju zvučni tomograf prikazao je manji udio zdravog drva (kategorija 1) i veći udio početne truleži drva (kategorija 2) na tomogramima u odnosu na stvarno stanje, dok je udio jače razgrađenog drva (kategorija 3) i šupljina (kategorija 4) bio točno prikazan.

Uporabom zvučnog tomografa, u arborikulturnoj dijagnostici, smanjuje se mogućnost ostavljanja opasnih stabala, čije drvo je degradirano gljivama truležnicama, kod kojih je veći rizik za lom stabla i nastanak štete. Točnom interpretacijom rezultata zvučnog tomografa, uz poznavanje čimbenika koji utječu na dobiveni prikaz tomograma, unaprjeđuje se vizualna prosudba urbanih stabala. Ovim pristupom moguće je sačuvati brojna stara i vrijedna stabla koja su ugrožena gljivama truležnicama, čime se utječe na povećanje koristi od stabala u urbanom okolišu.

\section{ZAHVALA}

\section{ACKNOWLEDGEMENT}

Rad je napravljen u sklopu projekta „Mjere prilagodbe klimatskim promjenama za održivo upravljanje prirodnim resursima - MEMORIE“ ,koji je financiran iz operativnog programa Konkurentnost i kohezija 2014 - 2020. „Shema za jačanje primijenjenih istraživanja za mjere prilagodbe klimatskim promjenama“, (ref. oznaka: KK.05.1.1.02).

\section{LITERATURA}

\section{REFERENCES}

- Abramoff, M.D., P.J. Magalhães, S.J. Ram, 2004: Image processing with ImageJ, Biophotonics international, Vol. 11 (7): 36-42.

- Allison, R. B., X. Wang, C.A. Senalik, 2020: Methods for Nondestructive Testing of Urban Trees, Forests, 11 (12): 1341; doi:10.3390/f11121341.

- Arciniegas, A., F. Prieto, L. Brancheriau, P. Lasaygues, 2014: Literature review of acoustic and ultrasonic tomography in standing trees, Trees, Vol. 28 (6): 1559-1567.

- Brazee, N.J., R. E. Marra, L. Gocke, P. van Wassenaer, 2011: Nondestructive assessment of internal decay in three hardwood species of northeastern North America using sonic and electrical impedance tomography, Forestry, 84 (1): 33-39.

- Bucor, V., 2005: Ultrasonic techniques for nondestructive testing of standing trees, Ultrasonics, 43: 237-239.

- Burcham, D., N.J. Brazee, R. E. Marra, B. Kane, 2019: Can sonic tomography predict loss in load-bearing capacity for trees with internal defects? A comparison of sonic tomograms with destructive measurements, Trees 33, 681-695.

- Cristini, V., J. Tippner, B.Vojáčková, V. Paulić, 2021: Comparison of variability in results of acoustic tomographs in pedunculate oak (Quercus robur L.), BioResources, 16 (2): 3046-3058.

- Deflorio, G., S. Fink, F. W. Schwarze, 2008: Detection of incipient decay in tree stems with sonic tomography after wounding and fungal inoculation, Wood Sci. Technol., 42 (2): 117-132.
- Espinosa, L., F. Prieto, L. Brancheriau, P. Lasaygues, 2019: Ultrasonic imaging of standing trees: factors influencing the decay detection, 2019 XXII Symposium on Image, Signal Processing and Artificial Vision (STSIVA). str 1-5.

- Gilbert, E. A., E. T. Smiley, 2004: Picus sonic tomography for the quantification of decay in white oak (Quercus alba) and hickory (Carya spp.), J. arboric., 30 (5): 277-281.

- Gilbert, G. S., J. O. Ballesteros, C. A. Barrios-Rodriguez, E. F. Bonadies, M. L. Cedeño-Sánchez, N. J. Fossatti-Caballero, M. M. Trejos-Rodríguez, J. Moises Pérez-Suñiga, K. S. Holub-Young, L. A. W. Henn, J. B. Thompson, C. G. García-López, A. C. Romo, D. C. Johnston, P. P. Barrick, F. A. Jordan, S. Hershcovich, N. Russo, J. David Sánchez, J. Pablo Fábrega, R. Lumpkin, H. A. McWilliams, K. N. Chester, A. C. Burgos, E. Beatriz Wong, J. H. Diab, S. A. Renteria, J. T. Harrower, D. A. Hooton, T. C. Glenn, B. C. Faircloth, S. P. Hubbell, 2016: Use of Sonic Tomography to Detect and Quantify Wood Decay in Living Trees, Appl Plant Sci, 4 (12): 1600060, DOI: 10.3732/apps.1600060.

- Gsell, S., D. Gsell, J. Dual, M. Motavalli, P. Niemz, 2009: Acoustic wood tomography on trees and the challenge of wood heterogeneity, Holzforschung, 63: 107-112. 10.1515/HF.2009.028.

- Gurda, S., 1999: Tehnologija drveta, Šumarski fakultet u Sarajevu, Sarajevo, Bosna i Hercegovina, 298 str.

- Johnstone D., G. Moore, M. Tausz, M. Nicolas, 2010: The Measurement of Wood Decay in Landscape Trees, Arboric Urban For, 36 (3): 121-127.

- Koizumi, A., T. Hirai, 2006: Evaluation of the section modulus for tree-stem cross sections of irregular shape, J. Wood Sci., 52(3): 213-219.

- Larjavaara, M., H.C. Muller-Landau, 2010: Comparison of decay classification, knife test, and two penetrometers for estimating wood density of coarse woody debris, Can. J. For. Res. 40: 23132321.

- Li, G., X. Wang, H. Feng, J. Wiedenbeck, R. J. Ross, 2014: Analysis of wave velocity patterns in black cherry trees and its effect on internal decay detection, Comput. Electron. Agric., Vol. 104: 3239. doi.org/10.1016/j.compag.2014.03.008.

- Liang, S., F. Fu, 2014: Effect of sensor number and distribution on accuracy rate of wood defect detection with stress wave tomography, Wood Res., Vol. 59 (4): 521-532.

- Leong, E.C., D. C. Burcham, Y.-K. Fong, 2012: A Purposeful Classification of Tree Decay Detection Tools, Arboric. J., 34 (2): 91115.

- Luo, Z., H. Guan, X. Zhang, 2019: The temperature effect and correction models for using electrical resistivity to estimate wood moisture variations, J. Hydrol., Vol 578: 124022, https://doi. org/10.1016/j.jhydrol.2019.124022.

- Marra, R. E., N.J. Brazee, S. Fraver, 2018: Estimating carbon loss due to internal decay in living trees using tomography: implications for forest carbon budgets, Environ. Res. Lett. 13: 105004.

- Mattheck, C., H. Breloer, 1994: The body language of trees: A handbook for failure analysis, TSO, London, 240 str.

- Mattheck, C., 2007: Updated field guide for Visual Tree Assessment, Verlag Forschungszentrum Karlsruhe, 170 str.

- Nicolotti, G., L.V. Socco, R. Martinis, A. Godio, L. Sambuelli, 2003: Application and comparison of three tomographic techniques for the detection of decay in trees, J. Arbor. 29: 66-78.

- Nowak, D. J., J. F. Dwyer, 2007: Understanding the benefits and costs of urban forest ecosystems. In Urban and Community Forestry in the Northeast; Kuser, J.E., Ed.; Springer: New York, NY, USA, str. 25-46. 
- Ostrovský, R., M. Kobza, J. Gažo, 2017: Extensively damaged trees tested with acoustic tomography considering tree stability in urban greenery, Trees, 31 (3): 1015-1023.

- Paulić, V, 2015: Prosudba opasnih stabala korištenjem vizualnih metoda i arborikulturnih instrumenata, Doktorska disertacija, Šumarski fakultet, Zagreb, 296 str.

- Paulić, V., D. Drvodelić, S. Mikac, G. Gregurović, M. Oršanić, 2015: Arborikulturna i dendroekološka analiza stanja stabala divljeg kestena (Aesculus hippocastanum L.) na području grada Velike Gorice. Šumarski list, Vol. 139 (1-2): 21-34.

- Rinn, F., 2012: Arbotom: User manual, Heidelberg, Njemačka.

- Rust, S., 2017: Accuracy and Reproducibility of Acoustic Tomography Significantly Increase with Precision of Sensor Position, Journal of Forest and Landscape Research, Vol. 2(1): 1-6.

- Tarasiuk, S., G. Jednoralski, K. Krajewski, 2007: Quality assessment of old-growth Scots pine stands in Poland, U: M. Grześkiewicz (ur.), Quality control for wood and wood products, Warsaw University of Life Sciences, Warsaw, Poland, str. 153-160.

- TIBCO Software Inc. 2018: Statistica (data analysis software system), version 13. http://tibco.com.

- Tikvić, I., D. Ugarković, I. Peles, I. Knežić, G. Medunić-Orlić, S. Marinić, L. Butorac, A. Čmrlec, R. Koharević, M. Nazlić, S. Pavlinović, M. Špika, R. Tomić, 2017: Procjene usluga šumskih ekosustava i općekorisnih funkcija šuma Park šume Marjan u Splitu. Šumarski list, Vol. 141 (5-6): 277-285.

- Tomiczek, C., D. Diminić, T. Cech, B. Hrašovec, H. Krehan, M. Pernek, B. Perny, 2008: Bolesti i štetnici urbanog drveća, Šumarski institut, Jastrebarsko, Šumarski fakultet Sveučilišta u Zagrebu, 384 str.

- Tyrväinen, L., S. Pauleit, K. Seeland, S. De Vries, 2005: Benefits and Uses of Urban Forests and Trees, U: C. Konijnendijk, K. Nilsson, T. B. Randrup, J. Schipperijn (ur.), Urban forests and trees, Springer, Berlin, Heidelberg, str. 81-114.
- Schneider, C. A., W. S. Rasband, K. W. Eliceiri, 2012: NIH Image to ImageJ: 25 years of image analysis, Nat. Methods, 9 (7): 671675.

- Sabadi, R., 1996: Uporaba hrastovine, U: D. Klepac, J. Dundović, J. Gračan (ur.), Hrast lužnjak (Quercus robur L.) u Hrvatskoj, HAZU, Vinkovci-Zagreb, str. 331-371.

- Škarica, T., 2019: Procjena površine zdravog drva zvučnim tomografom kod stabala hrasta kitnjaka u Parku Maksimir, Diplomski rad, Sveučilište u Zagrebu Fakultet šumarstva i drvne tehnologije, 31 str.

- Ugarković, D., M. Matijević, I. Tikvić, K. Popić, 2021: Neka obilježja klime i klimatskih elemenata na području grada Zagreba. Šumarski list, Vol. 145 (9-10): 479-488.

- van Wassenaer, P., M. Richardson, 2009: A Review of Tree Risk Assessment using minimally invasive technologies and two case studies, Arboric. J., Vol. 32, 275-292.

- Vitasović Kosić, I., B. Aničić, 2005: Istraživanje socioloških aspekata parka Maksimir, J. Cent. Eur. Agric., Vol. 6 (1): 77-84.

- Wang, L., H. Xu, C. Zhou, L. Li, X. Yang, 2007., Effect of sensor quantity on measurement accuracy of log inner defects by using stress wave, J. For. Res., Vol. 18 (3): 221-225.

- Wang, X., R.B. Allison, 2008: Decay detection in red oak trees using a combination of visual inspection, acoustic testing, and resistance microdrilling. Arboric Urban For, 34 (1): 1- 4.

- Wang, X., J. Wiedenbeck, S. Liang, 2009: Acoustic tomography for decay detection in black cherry trees, Wood Fiber Sci, 41: 127137.

- Yue, X, L. Wang, J.P. Wacker, Z. Zhu, 2019: Electric resistance tomography and stress wave tomography for decay detection in trees - a comparison study. PeerJ 7:e6444 https://doi.org/10.7717/ peerj.6444.

- *Struna Hrvatsko strukovno nazivlje: URL: http://struna.ihjj.hr (pristupljeno 20.09.2021).

\section{SUMMARY}

Urban trees and forests contribute to citizens' wellbeing and provide a wide range of benefits. Yet in the urban environment, trees are exposed to a range of abiotic and biotic factors that can impair growth. Wood decay fungi are a major cause of tree failure. Devices supported methods that measure certain wood properties are often used in addition to visual assessment of urban trees. Acoustic tomography is a device that measures the velocity of sound wave propagation through wood in the radial and tangential directions and is used to assess internal defects in trees. The aims of this study were to determine the size and position of healthy and decayed wood and to define the accuracy of acoustic tomography on ten old sessile oak trees in the Maksimir Forest Park, Zagreb. Results of acoustic tomography images (tomograms) were compared with photographs of tree cross sections after felling to confirm decay. The visual assessment indicated the presence of decay on ten trees, and this decay was visible on eight of ten tomograms. Decay was further confirmed in seven cross-sections after felling. Of these, three trees had incipient wood decay, while four had active wood decay with cavity formations. The shape of tomograms and position of decay were similar to the cross-section photographs for eight and nine trees, respectively. The area of decayed wood in different wood condition categories was correctly shown on the tomograms in comparison with the cross-section photographs in six of the trees. Acoustic tomography underestimated the area of sound wood and overestimated incipient wood decay in comparison with the actual state of cross-sections, while the area of active degraded wood and cavities was accurately represented.

KEY WORDS: sessile oak, urban forest, arboriculture, acoustic tomography, decayed wood. 